\title{
A Comparative Analysis of Female Images in Vanity Fair and Jane Eyre
}

\author{
Lei Guo ${ }^{1}$, Qianru $\mathrm{Du}^{2 *}$ \\ ${ }^{1}$ Professor, English Department, North China Electric Power University, Baoding, China \\ ${ }^{2}$ The post-graduate student majoring in English language and literature of North China Electric Power University in China
}

DOI: $10.36348 /$ sjhss.2020.v05i07.002

| Received: 06.07.2020 | Accepted: 13.07.2020 | Published: 16.07 .2020

*Corresponding author: Qianru Du

\section{Abstract}

Jane Eyre and Vanity Fair are two classic books in which the female images of Jane and Rebecca have attracted many readers. There are some similarities and differences in the female images as written in these stories. This paper will analyze the two female images in the two books. The goal of this article is to analyze the impact that environment and society have exercised on characters, and further advocate correct values toward friendship, marriage and family.

Keywords: Vanity Fair, Jane Eyre, Rebecca, friendship, marriage and family values.

Copyright @ 2020: This is an open-access article distributed under the terms of the Creative Commons Attribution license which permits unrestricted use, distribution, and reproduction in any medium for non-commercial use (NonCommercial, or CC-BY-NC) provided the original author and source are credited.

\section{INTRODUCTION}

Just as Virginia Woolf once said that "the meaning of book lies in the relationship between thing in the eyes of the author and the thing itself'[1]. Jane Eyre was written by Charlotte Bronte in 1847 . The book mainly portrays Jane Eyre's experience from childhood to adulthood. The excellent part lies in the romantic love between Mr. Rochester and Jane Eyre. Jane Eyre is apt to express her emotions of love and hatred passionately. Vanity Fair, or A Novel Without a Hero is Thackeray's masterpiece. His book takes place in the upper society of Britain in the early 19 century. The title unfolds the dark side of the society. As the subtitle of the novel suggests, the story has neither a plot nor a hero; its whole story revolves around two women, Amelia Sedley and Rebecca Sharp. To better compare the two female images, this paper is organized into four sections. The first section focuses on the introduction. The second section is about the background of Jane Eyre and Rebecca. The third section concerns their separate attitude towards friendship, marriage and family. The fourth section is conclusion of the paper.

\section{Background of Jane Eyre and Rebecca}

The circumstances in which a person grows up have a potential effect on his or her character and attitudes towards life. To some degree, education also plays a significant role in shaping the characters of a person. Therefore, understanding the family background the protagonists have, and the education they receive, will contribute to our understanding not only the personality but also the values of Jane Eyre and
Rebecca Sharp, who are demonstrated on separate novel.

\section{The Background of Jane}

Jane is an orphan adopted by her uncle at Gateshead where she is treated badly by her aunt and cousins after the death of her uncle. Unfortunately, she is bilious and rude in the eyes of her aunt, so she is sent to the Lowood where she lives an abject poverty without provisions and clothes to meet her needs. Nevertheless, she makes friends and receives education which benefits her a lot and makes her an independent woman as a governess. Before Jane is sent to Lowood, she gathers her energies and launches then in this blunt sentences: "I declare I do not love you: I dislike you the worst of anybody in the world except John Reed [2]". Just because the environment where she lives makes a significant influence on her personality, she can speak out what she thought. Even if she lives uncle's house, she can fight with her older cousin who treats her unfairly and hurts her seriously and she can talk back to her aunt who is not sympathetic with her situation. Additionally, she prefers to speak her mind without concealing her emotions.

At Lowood, because of the shortage of financial aid Jane's feet were "wretched flayed and swollen to lameness by the sharp air of January [2]". Even if she has a rough time, she never complains what's happening to her. While facing harsh reality, she would rather become resolute, courageous and positive towards life, instead of being pessimistic or losing heart. 


\section{The Background of Rebecca}

Similarly, Rebecca also is subjected to misfortune that she has never been cherished in her childhood, because of the death of her mother, who is French. Although she is not an orphan with a father living with her, he cannot afford the school fees. Just as described in the novel: "She was born in a stricken family, and her father was an artist, and in that quality had given drawing lessons at Miss Pinkerton's school. He was a clever man; a pleasant companion; a careless student; with a great propensity for running into debt, and a partiality for the tavern [3]."

Living in such a society makes Rebecca more mature and independent than her peers, she could deal with people her father owed money. She even learns how to contact with different people from all walks of life by taking advantage of attractive appearance. When Minerva asks her to teach children music without salary, she replies: "Give me money, and I will teach them [3]". This is an audacious behavior to offend Miss Minerva. Miss Minerva is strict with Rebecca, but she is not daunted and know how to respond to the unfair treatment. The reason why she is so valiant is that she inherited great talent from her mother so that she could speak French fluently. More importantly, she acquires excellent skills of playing the piano. Just as one saying goes, boldness of execution stems from superb skills. While she has tasted a great variety of bitterness, she is still optimistic after being left on the world without the help of parents. As long as she leaves Pinkerton's school, she plans to find a good husband for herself.

\section{Their Attitude Towards friendship, Marriage and Family}

Jane is a loyal friend; her conversation with Helen is candid. "But I feel this, Helen; I must dislike those who, whatever I do to please them, persist in disliking me; I must resist those who punish me unjustly [2]". She says what she thought and she had nothing to withhold from Helen. What's more, Jane attaches great importance to the friendship between her and Helen. When Helen is going to die, she takes the risk of getting infected to see her. What she does, to some degree, indicates that Jane is innocent and sincere. Compared with death, friendship transcends everything. Helen is her treasured friend with whom she shares joys, sorrows when she feel a sense of happiness or desperation.

Jane is independent in marriage, and she supports her life by herself without looking for a shortcut to change her fate. She gives priority to spiritual communication rather than material things. She is honest and resolute to her lover. Love is essential and integral to marriage in her eyes, so she refused St. John's proposal. For example, when asked the reason, she answered that "because you did not love me; now, I reply, because you almost hate me. If I were to marry you, you would kill me. You are killing me now [2]".
Even though St. John who was handsome, could give her the aid she wanted, she still chose to reject him. Jane Eyre abandoned mundane prejudice that the gap of class could be a barrier for marriage. She pursues independence and liberty in marriage, and she believes that she is equal with her master even though she is just a governess. Just as she said that "it is my spirit that addresses your spirit; just as if both had passed through the grave, and we stood at God's feet, equal,---as we are [2]". She never anticipates changing her fate by the ladder of marriage. Although she inherits a large fortune from her uncle, she still marries Mr. Rochester who is crippled, blind, and impecunious. Jane was eager for harmonious family because she never tasted the happiness in her uncle's family after the death of her uncle. After undergoing misfortune, she is not only loyal to her marriage but also pious as a Christian to look after her family. Most importantly, Jane is one of the few women who choose Rochester as her husband without considering the wealth and fame, just because she is interested in the person underneath.

However, Rebecca has a completely different attitude towards friendship, marriage and family. She is a talented and tactical woman, but also an adventuress embodying the many vices of the society. In schoolmaster's eyes, Rebecca is cunny because she should strike a bargain with her that she will be paid for teaching students piano lessons. At school, she makes friend with Amelia who comes from wealthy family. As a young girl,she must find good husband for herself due of the death of parents. All of this contributes to her selfish and realistic personality so that she regards friendship between Amelia and her as a chance to encounter an affluent man who can help her get rid of the beggarly life. At Amelia's family,she flirts with her older brother who is not only bashful but also cowardly. Besides, while facing the money there is no real friendship in her inner heart, she betrays Amelia and flirts with her best friend's husband.

Generally speaking, she is not loyal to her marriage. People are not innocent individuals in her eyes, but a ladder that she climbs to integrate into the upper class. By using her cleverness and tenderness, she marries with Rawdon for she believes that Rawdon will inherit a large fortune from her aunt. For Rebecca, money is superior to anything. If the man that she will marry had have a large fortune, she would not have minded his looks, age, and personality. As long as the man who is rich can make her life a carefree life. Unexpectedly, her husband is deprived of right of inheritance for their marriage which Rawdon's aunt disagrees with. Without sufficient money to support their luxurious life, Rebecca tried her best to make both ends meet. Marriage is a shelter under which she could flirt and contact with men who have fame and fortune. 
As is mentioned in The Second Sex: "Mother's love is not intuitive, natural, and in any case, the word "nature" is applicable to human beings [4]". In the male-dominated society, she plays the role of husband to earn money. Since the birth of her son Rawdon Junior, Rebecca spares no time for him and shows no sign of loving her son. Rebecca's attitude to her son is cold and indifferent. In his first month, Rebecca finds a nurse living in a village to look after him. The nurse treats Rawdon better than his mother. The environment where she lives has a significant impact on her life so she doesn't know how to love her son and do what she should as a mother. Her goal is crucial to her and she will not let anything preclude her determination to join the upper class. Ultimately, her husband abandons her because of her unusual relationship with other man, and her child has no affection for her because of her indifference. Loyalty, family and friendship is completely ignored by Rebecca. After the catastrophe, she tries to win her fame over and reenter into the upper class. What makes readers impressive is that she remains elegant regardless of scandals and contempt with the determined mind and affirmative heart.

\section{CONCLUSION}

In $19^{\text {th }}$ century, if women wanted to have equal right with men, they need to have strong hearts, optimistic attitudes and an aggressive approach in the face of difficulties, realizing frustration and catastrophe are inevitable in life. It is hardship and misfortune that make women stronger. From the two books, we find that Jane is "courageous, authentic, docile, diligent, disinterested, faithful, constant; very gentle, and very heroic [2]". While Rebecca is independent, ambitious, courageous, selfish. However, each of them has their own virtues and evils. They are independent individuals seeking their own happiness in different ways. Maybe, Rebecca is not a model because her actions and her values are disdained by most people. Nonetheless, I believe if she had been a male in that age, her fate would have dramatically changed. In a word, we should learn to develop correct attitude toward friendship, marriage and family.

\section{REFERENCES}

1. Virginia, W. (2014). A Room of One's Own [M]. Translated by Wu Xiaolei, Shanxi Normal University Press.

2. Bronte, C. (1993). Jane Eyre [M]. Washington: The University of Washington.

3. Thackeray, M. (1945). William. Vanity Fair [M]. London: J. M. Dent\& Sons Led.

4. Beauvoir, S., de. (1952). The Second Sex [M]. New York: Alfred A. Knoph, Inc. 